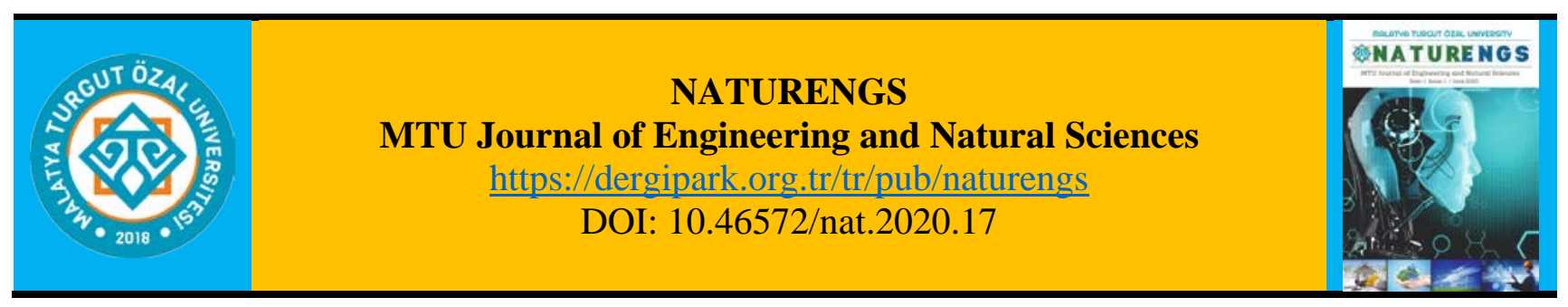

\title{
Determination of Consumer Preferences for Goose Meat Using Conjoint Analysis
}

\author{
Selim GÜNDÜZ* \\ Department of Business, Faculty of Business Administration, Adana Alparslan Turkes Science and Technology \\ University, Adana, Turkey.
}

(Received: 22.12.2020; Accepted: 30.12.2020)

\begin{abstract}
This study examines the consumer preferences for goose meat purchases of consumers who had previously purchased goose meat. The main purpose of this study is to determine which factors are more important for consumers when purchasing goose meat. Accordingly, the conjoint analysis technique, which is one of the multivariate statistical analysis methods, is used to determine the factors affecting goose meat purchases and the reasons for preferring goose meat. According to data of the Turkish Statistical Institute (TURKSTAT) for 2019, $44.07 \%$ of the goose population of Turkey $(1,157,049)$ spread among the provinces of Kars $(27.26 \%)$, Ardahan (8.68\%), and Mus (8.13\%). A sample of 172 people was selected by using the convenience sampling technique, one of the non-probability sampling methods, among the people who lived or have been living in these provinces and consumed goose meat. Market research and a questionnaire, which was prepared to determine consumer preferences, were conducted on this sample. According to the results of the analysis, the most significant factor determining the consumer preference for goose meat was found to be the price of goose meat per kilo (37.3\%). This was followed by the region where the goose was raised (32.8\%), the place where the goose meat was sold (21.6\%), and the presence of the product label (8.3\%) with the identification information of the product. Considering the results of the data obtained from the study, it is thought that the market share of the goose meat will increase if its recognition is increased by applying a reasonable pricing strategy, and standardizing the quality of the product.
\end{abstract}

Keywords: Goose meat, Consumer preferences, Market research, Conjoint analysis.

\section{INTRODUCTION}

Contrary to popular belief, the development level of countries cannot be increased only by investment in industry and service sectors. Developed countries make serious investments in agriculture and animal husbandry as well, and they are observed to be at a level that at least meets their needs in these fields. As a result, the gains obtained from agriculture and animal husbandry and the budgets to be transferred to these sectors can be indirectly used in industry and service sectors [1]. It should also be kept in mind that the countries' dependence on foreign food products will be eliminated in this way. Considering the increase in the rural population in Turkey and the increase in investments in the production of agricultural and goose products that can create added value, the income obtained from these products can be used in industry and service sectors, thereby contributing to the country's development level. Accordingly, it is 
required to complete the infrastructure and technological equipment in the agriculture and animal husbandry sectors immediately. Also, diversifying the products, and ensuring the sustainability of natural resources in the production, and increasing the income from these products are required for these sectors.

The most important factors that make up the competitive power of countries and institutions are the capacity of making innovations and utilizing the resources efficiently. The issues of production with low added value and not being able to utilize the potentials sufficiently are among the main problems of the less developed countries. Accordingly, it is projected that geese husbandry, which has been on the agenda of Turkey in recent years and producing goose meat and products will be an efficient production line for the domestic and foreign markets. Also, market research in this sector is considered quite crucial.

In the present study, market research was conducted on goose meat and products, which are expected to reach a significant sales volume in both domestic and foreign markets. First, the current situation in the production and consumption of goose meat in Turkey was determined; then, the factors that affect the consumption preferences for goose meat and the effect sizes of these factors were determined by using the conjoint analysis technique, one of the multivariate statistical analysis methods. Within this context, the people who consumed goose meat or products were asked to answer the following questions: "For which features do you prefer these products?”, “The change of which parameters may increase the consumption? "Which features of these products should be brought to the fore if they are to be marketed in domestic and foreign markets?” This study is thought to contribute to the sector in terms of identifying the current status of goose husbandry and goose products consumption in Turkey, as well as determining the problems and providing solution proposals for the future. More research on goose husbandry will make important contributions to this production to be regarded as a sector. Goose husbandry, which has been carried out by traditional production methods, has not reached the desired level due to information pollution and lack of infrastructure [2]. It is important to carry out such studies to popularize this husbandry, which is highly competitive and value-added, as well as for promoting it as a sector. Moreover, it is thought that the studies in this field will provide important references for policymakers, executives who lead the sectors, institutions, and researchers.

The conjoint analysis used in the study is one of the multivariate analysis techniques preferred by researchers to determine the characteristics of consumer behavior [3]. The conjoint analysis provides important information to researchers on the following issues: matters to be considered in new product development studies; changes to be made in products or services and how these changes will be reacted by consumers; how and to what extent the general situation in the market will affect the products and services; how the balances in the market will change over time and with new products; how pricing will reflect on the market.

\section{CURRENT STATUS OF GOOSE MEAT PRODUCTION AND CONSUMPTION}

Many developing countries attach importance to animal husbandry in integrated production systems to achieve sustainable increases in the production of required food to meet the demands of a rapidly increasing population. Geese adapts well to this kind of systems and particularly to humid regions. They can be raised by natural grazing and are more resistant to diseases than other bird species. Even though goose has a long history dating back to 3000 BC in Egypt and it has inspired many books and stories, goose meat consumption has not been as popular as chicken and duck consumption [4]. The low economic significance of goose husbandry due to 
low breeding levels compared to other poultry or the limited geographical spread is considered the reason for this case. Although geese can withstand winter conditions in minimal outdoor shelters and can also adapt to warmer climates, commercial goose production is important only in a few countries in Asia and Europe.

Geese, which were first domesticated in Egypt in history, have been now raised almost anywhere in the world. Domesticated geese are raised for their meat, fatty liver, fat, and feathers, and they are usually consumed widely on Christmas [4]. Although goose breeding can be carried out under all climatic and geographical conditions, it is believed that goose breeding is more yielding in cold and wetlands.

Goose production in Turkey is carried out only by small family businesses using traditional methods, and it seems that major investments have not been made in this field [5]. Goose production is carried out by these enterprises in many provinces, particularly in Kars and Ardahan, and consumed by the local people. Since a production system identified with this consumption understanding has been established, these enterprises have not grown [6]. However, thanks to the increasing demand for goose meat in recent years, it has been observed that the interest in goose husbandry has also increased. Therefore, it has been observed that gaggles of geese have been brought to Kars and Ardahan from various provinces for fattening. Moreover, the number of goose population has increased in many provinces [2]. The production can be extended by increasing the consumption network of goose meat and its products. This can be achieved by increasing the market share of the products. It is seen that goose meat has reached large cities in recent years due to the demands of people who have traditional consumption habits. Thus, traditional dishes are served in large cities. Thanks to this dynamism, the goose trade has emerged across Turkey, which has increased the interest in production [7].

The production cost of poultry such as chicken, turkey, duck, goose, and quail is lower compared to red meat. Moreover, the popularity of poultry has been increasing in many countries due to the short breeding period of these animals and the high nutritional value of their meat. Since poultry has high protein, low calorie, and low cholesterol levels, their consumption has been increasing each passing day across the world. Besides these features, the connective tissue rate of poultry is lower than that of red meat; therefore, it is easier to digest [8].

The goose, which is the first poultry fed by humans, grows later than other poultry. However, their immune system is better than that of other poultry; thus, they do not get sick easily and show more resistance to cold climatic conditions [8]. Goose meat has an important role in human nutrition since it is a good source of protein and contains essential amino acids, particularly arginine, and high unsaturated fatty acids [9].

Goose husbandry offers significant advantages since it can adapt to various climate conditions and utilize natural resources well. However, goose husbandry is limited in Turkey and carried out only in particular provinces. Table 2 presents the numbers of goose population by provinces according to TURKSTAT's data for 2019 [10]. The number of geese population is quite low compared to the numbers of chicken and turkey populations (Table 1). This is due to the insufficient retail consumption and consumer preference for goose products in the domestic market. However, it offers several advantages over substitute products in terms of nutritional values (Table 3). 
Table 1. The numbers of poultry population by years in Turkey (x1000) (TURKSTAT)

\begin{tabular}{|c|c|c|c|c|}
\hline Years & Broiler Chicken & Turkey & Goose & Duck and Guinea Fowl \\
\hline 2005 & 257,221 & 3,697 & 1,067 & 656 \\
\hline 2006 & 286,121 & 3,227 & 830 & 525 \\
\hline 2007 & 205,082 & 2,675 & 1,023 & 482 \\
\hline 2008 & 180,916 & 3,230 & 1,063 & 470 \\
\hline 2009 & 163,469 & 2,755 & 945 & 413 \\
\hline 2010 & 163,985 & 2,942 & 716 & 397 \\
\hline 2011 & 158,917 & 2,563 & 680 & 382 \\
\hline 2012 & 169,034 & 2,761 & 676 & 357 \\
\hline 2013 & 177,433 & 2,925 & 755 & 368 \\
\hline 2014 & 199,976 & 2,990 & 912 & 400 \\
\hline 2015 & 213,658 & 2,828 & 851 & 398 \\
\hline 2016 & 220,322 & 3,183 & 933 & 414 \\
\hline 2017 & 221,245 & 3,872 & 978 & 492 \\
\hline 2018 & 229,507 & 4,043 & 1,080 & 533 \\
\hline 2019 & 221,842 & 4,541 & 1,157 & 519 \\
\hline
\end{tabular}

According to Table 1, the number of broiler chickens in Turkey decreased gradually between 2006 and 2011, however it has started to increase again after 2012. Table 2 also reveals that there is an increasing trend in the number of geese, particularly in the last 5 years. Moreover, the numbers of ducks and guinea fowls also increased in these years together with geese.

Table 2. Provinces with a geese population of more than 10,000 in 2019 and their percentages (TURKSTAT)

\begin{tabular}{|c|c|c|c|c|c|c|c|}
\hline Rank & Province & Number & Percentage & Rank & Province & Number & Percentage \\
\hline 1 & Kars & 315,375 & $27.26 \%$ & 14 & Ankara & 17,475 & $1.51 \%$ \\
\hline 2 & Ardahan & 100,429 & $8.68 \%$ & 15 & Cankiri & 16,639 & $1.44 \%$ \\
\hline 3 & Mus & 94,036 & $8.13 \%$ & 16 & Erzincan & 16,315 & $1.41 \%$ \\
\hline 4 & Kutahya & 42,321 & $3.66 \%$ & 17 & Agri & 15,719 & $1.36 \%$ \\
\hline 5 & Samsun & 34,869 & $3.01 \%$ & 18 & Amasya & 15,167 & $1.31 \%$ \\
\hline 6 & Afyon & 34,835 & $3.01 \%$ & 19 & Sirnak & 14,528 & $1.26 \%$ \\
\hline 7 & Yozgat & 28,375 & $2.45 \%$ & 20 & Eskisehir & 14,438 & $1.25 \%$ \\
\hline 8 & Corum & 28,264 & $2.44 \%$ & 21 & Aksaray & 14,096 & $1.22 \%$ \\
\hline 9 & Sanliurfa & 22,967 & $1.98 \%$ & 22 & Kirsehir & 12,025 & $1.04 \%$ \\
\hline 10 & Diyarbakir & 21,732 & $1.88 \%$ & 23 & Edirne & 10,791 & $0.93 \%$ \\
\hline 11 & Konya & 18,401 & $1.59 \%$ & 24 & Elazig & 10,747 & $0.93 \%$ \\
\hline 12 & Erzurum & 17,755 & $1.53 \%$ & 25 & Tokat & 10,425 & $0.90 \%$ \\
\hline 13 & Adana & 17,629 & $1.52 \%$ & \multicolumn{2}{c|}{ Turkey } & $\mathbf{1 , 1 5 7 , 0 4 9}$ \\
\hline
\end{tabular}

As shown in Table 2, 44.07\% of the goose population in Turkey spread among the provinces of Kars (27.26\%), Ardahan (8.68\%), and Mus (8.13\%). Table 1 also reveals that the goose population of 25 provinces is more than 10,000 and goose husbandry can be carried out in any region of Turkey. However, it is obvious that Northeastern Anatolia has a key role in goose husbandry, and it is distinguished from other regions in Turkey. 
Table 3. The energy and nutritional values of edible parts of various meats (100 grams) [7]

\begin{tabular}{|l|c|c|c|c|c|c|}
\hline Meat Type & $\begin{array}{c}\text { Price } \\
(\mathbf{1 ~ k g )}\end{array}$ & $\begin{array}{c}\text { Energy } \\
\text { (cal) }\end{array}$ & $\begin{array}{c}\text { Protein } \\
\mathbf{( g )}\end{array}$ & $\begin{array}{c}\text { Fat } \\
\mathbf{( g )}\end{array}$ & $\begin{array}{c}\text { Calcium } \\
(\mathbf{m g})\end{array}$ & $\begin{array}{c}\text { Iron } \\
(\mathbf{m g})\end{array}$ \\
\hline Cattle (semi-fat) & 50 & 240 & 18.7 & 18.2 & 8 & 2.6 \\
\hline Sheep (semi-fat) & 55 & 267 & 17.0 & 21.0 & 7 & 2.2 \\
\hline Chicken & 10 & 149 & 19.0 & 8.0 & 15 & 1.5 \\
\hline Rabbit & 40 & 137 & 21.0 & 5.8 & 17 & 1.6 \\
\hline Goat & 55 & 157 & 18.4 & 9.2 & 1 & 2.2 \\
\hline Turkey & 25 & 144 & 19.5 & 6.7 & 17 & 1.7 \\
\hline Goose & 70 & 161 & 22.8 & 7.1 & 13 & 2.6 \\
\hline
\end{tabular}

\section{LITERATURE REVIEW}

With its ecological suitability, feasibility for small businesses, favorable geographical location for the EU and the Middle East market in terms of foreign trade, Turkey has ideal conditions for goose production. On the other hand, considering the changes in consumption patterns, increasing popularity of out-of-home consumption, increasing trend of healthy food consumption, being an alternative for the animal protein needs of the growing population, presence of consumers seeking for new products, the widespread use of local flavors as a touristic instrument, it reveals the existing goose production and consumption potential in Turkey. For these and similar reasons, many studies have been conducted recently to investigate the importance of goose breeding, goose meat and goose products. Some of these studies are given below.

Gunduz et al. (2019) conducted a sensory analysis on goose meat and the substitute products [7], while Boz and Sarica (2018) conducted a study on the current status and future of goose husbandry in Turkey [6]. Sarica (2018) performed applied research on increasing the yield of domestic goose [5], and Sekeroglu and Duman (2018) analyzed goose products and the ways of consuming them, and they researched their marketing structure and the current situation in the legislation [4]. Yamak (2018) performed studies on the breeding and incubation methods in geese [11], Kirmizibayrak (2018) studied the barriers for goose husbandry in Turkey [2], Arslan (2018) studied feeding methods according to goose production systems [12], Saatci (2018) examined hygiene and preventing diseases in goose husbandry [13]. Additionally, Tekbalkan (2017) studied traditional dishes of goose meat [14], Guner et al. (2002) compared goose salami with turkey salami and chicken salami to determine its suitability for consumption, thereby introducing goose meat to meat products technology [15]. Askin and Ilaslan (1976) researched Kars geese's several characteristics with economic importance [16].

Conjoint analysis, one of the multivariate statistical techniques, was used in this study, which can be regarded as market research on goose meat and its products. This analysis is a method that is frequently used especially in the field of marketing, and many academic studies have been conducted in market research in recent years using this method. The first studies on the conjoint analysis, which was used in the present study, were made in the 1920s. Then, R. Duncan Luce and John W. Tukey reported the importance of the "Conjoint Measurement" in their study in 1964 [17]. Although several studies were conducted and software applications were developed after this article, the first consumer-oriented study was carried out by Paul Green and Vithala R. Rao in 1971 [18]. The study conducted by Green and Srinivasan in 1978 has been a reference for many studies using conjoint analysis [3, 19]. 
Other studies using conjoint analysis are given below. These studies are presented in chronological order, and particularly, the studies conducted in recent years are presented.

Alvarez-Farizo and Hanley (2002) used conjoint analysis in their studies and showed how two choice modeling techniques can be used to estimate the potential environmental impacts of wind farm developments [20]. Poortinga et al. (2003) examined the preferences for various energy-saving measures using Part-worth conjoint analysis [21]. Sen and Cemrek (2004) conducted an applied study using conjoint analysis to determine the student preferences for private teaching institutions [22]. Saracli and Siklar (2005) examined the factors that affect the preference for Private Pension System using conjoint analysis [18]; Camlidere (2005) conducted a study on mobile phone purchases using conjoint analysis [23]; Tatlidil (2015) defined the political leader profile using conjoint analysis [24], and Catpinar (2005) researched preferences for private health insurances using conjoint analysis [25]. Dikici (2006) conducted a thesis study on determining consumer preferences for mobile phones using conjoint analysis [26]. Sonmez (2006) conducted a study on consumer preferences for computer purchases using conjoint analysis [27]. On the other hand, Akinci et al. (2007) made an application on adaptive conjoint analysis and discount markets in Istanbul. Soykan (2009) used conjoint analysis on purchasing decisions in the industry [28]. Dinc (2010) used conjoint analysis to determine the automobile selection criteria for consumers [29], and Filiz and Sengoz (2010) also examined the consumer preference for casco insurance using this analysis method [30]. Turanli et al. (2011) analyzed mobile phone consumer preferences for GSM plans and price elasticity using conjoint analysis [31], while Cevik and Yigit (2011) determined consumer preference for office furniture using conjoint analysis [32]. Bridges et al. (2011) presented the findings of their analysis as the following ten-item checklist: Research question, attributes and levels, construction of tasks, experiment design, preference elicitation, instrument design, data collection, statistical analyses, results, and conclusion, and the study presentation [33]. Aktas et al. (2012) conducted an applied study on the performances of conditional logit analysis and conjoint analysis in the modeling of the polychotomous dependent variable [34]. Sahinkanat (2013) analyzed the purchasing decisions of consumers using conjoint analysis in her master's thesis [35]. Yavuz and Cemrek (2013) examined the healthcare professionals' preferences for housing using conjoint analysis [36]. Turanli et al. (2013) identified the factors affecting consumer preferences for the newspaper using this analysis [31], and Ceylan (2013) published a study on market segmentation based on benefit in the retail sector by using conjoint and cluster analysis [37]. Baki et al. (2017) analyzed consumer preferences for honey in Izmir, Turkey by conjoint analysis [38]. Yildiz ve Kucukkancabas (2020) investigated the effects of eco-labels on consumer behaviors using conjoint analysis [39]. Finaly, Li et al. (2020) in their study examined the public preference for electric vehicle incentives in China based on a large sample ( $n=1039$ ) using the conjoint analysis for incentive policies [40]. The results of the study revealed that less than a third of consumers had a better understanding of incentive policies, while more than half had little information about these policies. According to consumers, the relative importance levels of various policy categories are ranked as follows: charging incentive policies, driving incentive policies, vehicle registering incentive policies, and purchasing incentive policies.

\section{CONJOINT ANALYSIS}

In the present study, conjoint analysis, which is one of the multivariate statistical techniques, was used to examine consumer preferences for goose meat. Also, the benefits attributed to the characteristics of this product (goose meat) by the consumers were determined. Because this analysis is based on the estimation of the utility functions of individuals, it measures the 
relationship between the reactions of consumers to products or services and the features of these products and services. Determining consumer preferences using conjoint analysis allows the consumer to provide a preference degree for each quality level of the product or service, as well as to make preliminary preparation about possible future situations [3]. Due to this feature, it provides an opportunity to gain an insight into the product or service combinations that are planned to be released in the future, to determine the most important factor for the consumer, thereby offering the opportunity to run advertisement and promotion campaigns using the relevant variable.

The conjoint analysis allows determining the optimal features of a product or service, consumer choices, and estimating the weights attached to various factors in the decision-making process [38]. For example, consumers consider factors such as the number of rooms, location, price, transportation, etc. for house purchases and choose by evaluating them according to their importance levels. Similarly, the consumers determine the optimal choices for themselves when buying a car by considering the criteria such as body type, brand, fuel type, fuel consumption, brand, price, etc. If these tendencies of the consumers are determined accurately, the contractors can choose effective construction areas and types accordingly, and automobile manufacturers can revise their production lines in line with these demands.

What distinguishes Conjoint Analysis from other statistical analyses is that it provides the opportunity to compare the qualities quantitatively [18]. With the relationship between the variables determined for a particular product or service, the relationship levels between these variables, and the importance levels of these variables are converted into data that can be expressed numerically. In particular, conjoint analysis is used to understand how respondents develop their preferences for products and services [41]. Conjoint analysis is a common market research technique used in designing new products and improving existing products. Also, it is used for getting an advantageous position in the market compared to the competitors, measuring the effect of price on purchasing behavior, and estimating market share [42].

The value given by customers to each separable feature of a product is determined by conjoint measurement; thus, the most affordable product with the most suitable features is determined. The purpose of this study is not to measure the purchasing intentions of customers, but to determine the preference by evaluating the price and non-price features that are important in the choice of the product.

Multivariate statistical analysis techniques have been developed since multiple statistical techniques have to be used at the same time in many disciplines. The assumption of normality required in these techniques, the application of algorithms that generate complex and general results have led to the emergence of various issues and challenges. In some studies, modern methods were developed to determine relationships when several variables could not be measured actually and therefore they were defined qualitatively [43]. One of these modern methods is the conjoint analysis, which is also used in this study. As a multivariate statistical method developed by mathematician psychologists, conjoint analysis allows analyzing the effects of factors concerning human attitudes and behavior, as well as estimating the value of products and services for the consumers [17]. The conjoint analysis differs from other multivariate statistical methods in terms of reflecting consumer preferences and decisions more realistically. These differences can be observed in the following areas: segmentation/segregation difference, types of relationships between dependent/independent variables, and the possibility to make estimations at the individual level. In other words, consumer preferences can be divided according to each feature of the products using conjoint 
analysis, and these discrete relationships can be easily calculated even if there is no linear relationship between dependent/independent variables. Moreover, estimations can be made at individual levels using different preference models for each unit instead of making a cumulative estimation.

Conjoint analysis can be expressed by the following equation. In this equation, the $Y$ variable can be measured using a classifier, sorter, or an equidistant scale, while $X 1, X 2, \ldots, X p$ variables may be measured using a classifier or a sorting scale [44].

$$
Y_{i}=X_{1}+X_{2}+\cdots+X_{p}, \quad i=1,2, \ldots, n
$$

Conjoint analysis is divided into the following three categories: Adaptive Conjoint Analysis, Selection-Based Conjoint Analysis, and Conjoint Value Analysis [18]. Determining the most appropriate Conjoint Analysis method for the research subject is important to obtain the desired results.

It is necessary to follow a specific strategy not to make the process complicated and to obtain accurate estimates when performing conjoint analysis. First of all, determinant factors of the product or service to be analyzed and the levels of these factors should be identified. Secondly, the combinations of these factors and levels should be determined. Considering that the number of combinations will be high when the number of these factors and levels are high, models that reduce these numbers should be used to facilitate consumer assessment. In the third step, determined combinations of various factors and levels should be presented in cards or opinion forms to the respondents. Finally, the estimation model is determined.

\section{APPLICATION}

According to data of the Turkish Statistical Institute (TURKSTAT) for 2019, the provinces of Kars (27.26\%), Ardahan (8.68\%), and Mus (8.13\%) have the $44.07 \%$ of the goose population of Turkey $(1,157,049)$. The primary material of the study is the data obtained by a questionnaire study conducted with people who lived or have been living in these cities and consumed goose meat. The questionnaire form, which was prepared after a detailed literature review, was revised after a pilot study. A sample of 172 people was selected by using the convenience sampling technique, one of the non-probability sampling methods, among the people who lived or have been living in these provinces and consumed goose meat. Then, the questionnaire was applied face-to-face. The data obtained from the responses of 172 people, whose responses were appropriate and complete, were used in the analysis. The number of participants meets the condition of the minimum number of responses $(>150)$ for the Conjoint analysis [45]. Publications on goose meat consumption and conjoint analysis in national and international literature, reports, and statistics prepared by relevant institutions and organizations are other materials used in this study.

The first part of the questionnaire form includes questions to determine the socio-economic characteristics of the participants. Findings regarding the demographic characteristics of consumers are presented in Table 4 . According to this table, $42 \%$ of the participants were women, $78.2 \%$ were married, and $25.3 \%$ had an associate degree or a higher degree. Moreover, it was determined that a significant part of the participants were housewives $(42.9 \%)$ and the income level of the majority (62.1\%) was 2,500 TRY or below. 
Table 4. Demographic Features of the Participants

\begin{tabular}{|c|c|c|c|}
\hline Gender & Percentage & Marital Status & Percentage \\
\hline Female & $42 \%$ & Married & $78.2 \%$ \\
\hline Male & $58 \%$ & Single & $21.8 \%$ \\
\hline Age (years) & Percentage & Level of Education & Percentage \\
\hline 25 and below & $10.2 \%$ & Primary school or below & $37.6 \%$ \\
\hline $25-40$ & $23.7 \%$ & High School & $37.1 \%$ \\
\hline $41-65$ & $58.9 \%$ & $\begin{array}{l}\text { Associate Degree or Bachelor’s } \\
\text { Degree }\end{array}$ & $24.5 \%$ \\
\hline 65 and above & $7.2 \%$ & M.Sc. Degree or above & $0.8 \%$ \\
\hline Profession & Percentage & Monthly Income (TRY) & Percentage \\
\hline Civil servant & $22.7 \%$ & Up to 2,500 & $62.1 \%$ \\
\hline $\begin{array}{l}\text { Private } \\
\text { sector/Self- } \\
\text { employed }\end{array}$ & $13.1 \%$ & $2,501-5,000$ & $28.3 \%$ \\
\hline Housewife & $42.9 \%$ & $5,001-7,500$ & $6.0 \%$ \\
\hline $\begin{array}{l}\text { Retired } \\
\text { Student }\end{array}$ & $\begin{array}{l}12.2 \% \\
9.1 \%\end{array}$ & More than 7,500 & $3.6 \%$ \\
\hline
\end{tabular}

As stated in the previous sections, the aim of this study is; to determine the order of importance of factors affecting consumer preferences while purchasing goose meat by using conjoint analysis. In this study, the order of preference was used as the dependent variable to determine the goose meat preferred by consumers. This variable has been measured with an interval scale and takes values between 1 and 16. Expert opinions and related literature were used while determining the independent variables and levels affecting goose meat purchasing preferences. The independent variables included in the analysis were determined as region, price, distribution and product label. The number of variables used in the study is 4 and the number of levels related to the variables is $3,3,3,2$, respectively. The total number of cards containing all possible combinations of levels is $3 * 3 * 3 * 2=54$. However, since the application of 54 cards is difficult, the orthogonal design was used. Syntax menu of SPSS package program was used to create the cards used in conjoint analysis. 18 cards were created using this program. 172 people in the study sample were asked to rank 18 cards from the most preferred to the least preferred. In the Conjoint analysis used in this study, the full concept technique was preferred as the data collection method. The full concept technique is a method where all features are evaluated together.

Table 5 presents the results of the conjoint analysis conducted to determine the goose meat purchasing preferences of the people who responded to the questionnaire. The features that the consumers consider when they buy goose meat such as the region where the goose is raised, the price, the place where the product is sold, and the presence of the product label, as well as the partial benefits and their relative importance values, are included in Table 5. 
Table 5. Partial benefits and their relative importance values calculated by conjoint analysis

\begin{tabular}{|c|c|c|c|}
\hline Feature & Sub-level & $\begin{array}{c}\text { Utility } \\
\text { (Benefit) }\end{array}$ & $\begin{array}{c}\text { Relative } \\
\text { Importance }\end{array}$ \\
\hline \multirow{3}{*}{ Region } & Eastern - Central Anatolia Regions & 0.985 & \multirow{3}{*}{$32.8 \%$} \\
\hline & Mediterranean - Southeastern Anatolia Regions & 0.326 & \\
\hline & Marmara - Aegean - Black Sea Regions & 0.112 & \\
\hline \multirow{3}{*}{ Price (TRY/Kg) } & 40 & 0.385 & \multirow{3}{*}{$37.3 \%$} \\
\hline & 60 & 1.128 & \\
\hline & 80 & -0.278 & \\
\hline \multirow{3}{*}{ Distribution } & Grocery - Supermarket & 0.358 & \multirow{3}{*}{$21.6 \%$} \\
\hline & Bazaar & 0.058 & \\
\hline & House - Farm & 0.296 & \\
\hline \multirow{2}{*}{ Product label } & Available & 0.218 & \multirow[b]{2}{*}{$8.3 \%$} \\
\hline & Not available & -0.218 & \\
\hline
\end{tabular}

According to the relative importance values of the features listed in Table 5, it is understood that the most effective factor in the consumer's preference for the purchase of goose meat is the price of goose meat per kilogram (37.3\%). Following this factor, the region where the goose is raised $(32.8 \%)$, where the product is sold $(21.6 \%)$, and the presence of the product label $(8.3 \%)$ affect consumer preferences.

The utility (benefit) coefficients are calculated to determine which levels of the variables each respondent desires most. Considering the partial benefit values of the price factor, which is the most effective factor on consumer preference, the highest benefit was found to be the price of 60 TRY per kg, while the lowest benefit was found to be the price of 80 TRY per kg. This can be interpreted that the consumers want to buy the goose meat cheaper than red meat, however, they do not prefer a product if the price per kg is very low considering the quality.

Following the price factor, the feature that most affects the purchasing preference is the region where the goose is raised. According to the levels of this factor, the highest benefit is obtained from the geese raised in the Eastern and Central Anatolia regions. According to the levels of the factor of the place where the product is sold, the highest benefit is obtained from the goose meat sold in popular supermarkets and the lowest benefit is obtained from the goose meat sold in bazaars. Finally, the presence of a product label that includes information on the expiration date of the goose meat and the place of slaughter was also found to have high benefit.

\section{CONCLUSION}

When the relevant literature is examined, it is obvious that goose meat will take place in the market, considering its superiority in terms of nutritional values compared to the substitute products and the positive evaluations of the participants according to the substitute products. Therefore, it will be beneficial to accelerate the production and sales process of goose meat and 
goose products that will contribute to the national economy in terms of added value. To achieve this acceleration, it is necessary to increase academic studies and market research in this field. In this direction, using conjoint analysis, which is a method frequently used in marketing research, consumers' buying behavior of goose meat was investigated in this study.

The participants of this study, which was conducted with 172 people who had previously purchased goose meat, $42 \%$ were women, $78.2 \%$ were married, and $25.3 \%$ had an associate degree or a higher degree. Moreover, it was determined that a significant part of the participants were housewives (42.9\%) and the income level of the majority (62.1\%) was 2,500 TRY or below.

Considering the results of the conjoint analysis in terms of the relative importance values, the price of goose meat per kilogram was found to be the most effective factor (37.3\%) affecting consumer preference for goose meat purchases. Following this, the factors of the region where the goose is raised (32.8\%), where the product is sold (21.6\%), and the presence of the product label (8.3\%) were found to affect consumer preferences for goose meat purchases.

According to the partial benefit values of the levels of the price factor, which is considered to have the most effect on the consumer preference for goose meat purchase, it is observed that the highest benefit is obtained at the price of 60 TRY per kg. Also, considering the level of the factor of the region where the goose is raised, the highest benefit is obtained from the geese raised in the Eastern and Central Anatolia regions, as expected. On the other hand, considering the factor of the place where the product is sold, the highest benefit is obtained from the goose meat sold at popular supermarkets. Also, considering the level of the product label factor, the presence of the product label was found to provide a high level of benefit.

It is important to know which properties of the product are important for the consumer and whether the product is preferred or not. It is necessary to find answers to these questions for a successful product and service design. In this study, it was tried to answer these questions for goose breeders.

\section{Acknowledgments}

This research was supported by the Scientific Research Projects Coordination Unit of Adana Alparslan Turkes University of Science and Technology within the scope of the scientific research projects (Project No: 18113008).

\section{REFERENCES}

[1] Kilci, A. E. (2018). Önsöz, Türkiye Kaz Yetiştiriciliği Çalıştayı ve Kaz Günü Etkinliği Sonuç Raporu, 11.

[2] Kırmızıbayrak, T. (2018). Türkiye'de Kaz Yetiştiriciliğinin Ticari Bir Sektör Olmasının Önündeki Engeller. Türkiye Kaz Yetiştiriciliği Çalıştayı ve Kaz Günü Etkinliği Sonuç Raporu, 22-23 February 2018, Yozgat, 53-68.

[3] Green, P.E., ve Srinivasan, V., (1978). Conjoint Analysis in Consumer Research: Issues and Outlook, Journal of Consumer Research, 5, 103-123.

[4] Şekeroğlu, A. and Duman, M. (2018). Kaz Ürünleri Pazarlama Yapısı, Mevzuattaki Durum ve Sorunları. Türkiye Kaz Yetiştiriciliği Çalıştayı ve Kaz Günü Etkinliği Sonuç Raporu, 22-23 February 2018, Yozgat, 110116.

[5] Sarıca, M. (2018). Yerli Kazlarımızda Seleksiyonla Verim Artışı Sağlanabilir mi? Bir Uygulama Projesi. Türkiye Kaz Yetiştiriciliği Çalıştayı ve Kaz Günü Etkinliği Sonuç Raporu, 22-23 February 2018, Yozgat, 45-52. 
[6] Boz, M.A. and Sarıca, M. (2018). Türkiye'de Kaz Yetiştiriciliğinin Durumu ve Geleceği. Türkiye Kaz Yetiştiriciliği Çalıştayı ve Kaz Günü Etkinliği Sonuç Raporu, 22-23 February 2018, Yozgat, 36-44.

[7] Gündüz, S., Dölekoğlu, C. Ö., and Say, D. (2019). Sensory Analysis with Goose Consumption Preferences Substitute Products. European Journal of Science and Technology, (16): 32-40.

[8] Oz, F., Celik, T., 2015. Proximate Composition, Color and Nutritional Profile of Raw and Cooked Goose Meat with Different Methods. Journal of Food Processing and Preservation, 39: 2442-2454.

[9] Liu, B. Y., Wang, Z. Y., Yang, H. M., Wang, J. M., Xu, D., Zhang, R., Wang, Q. (2011). Influence of Rearing System on Growth Performance, Carcass Traits, and Meat Quality of Yangzhou. Poultry Science, 90(3): 653-659.

[10] TSI, 2019. Turkish Statistical Institute. www.tuik.gov.tr. Access Date: 10.10.2010.

[11] Yamak, U. S. (2018). Kazlarda Üreme ve Kuluçka. Türkiye Kaz Yetiştiriciliği Çalıştayı ve Kaz Günü Etkinliği Sonuç Raporu. 22-23 February 2018, Yozgat, 69-84.

[12] Arslan, C. (2018). Kazların Ekstansif, Yarı Entansif ve Entensif Üretim Sistemlerine Göre Belirlenmesi. Türkiye Kaz Yetiştiriciliği Çalıştayı ve Kaz Günü Etkinliği Sonuç Raporu, 22-23 February 2018, Yozgat, 85-94.

[13] Saatci, M. (2018). Kaz Yetiştirmede Hijyen ve Hastalıklardan Korunma. Türkiye Kaz Yetiştiriciliği Çalıştayı ve Kaz Günü Etkinliği Sonuç Raporu, 22-23 February 2018, Yozgat, 95-109.

[14] Tekbalkan, M. (2017). The Role of Local and Regional Food in Local Tourism: Sample of Samsun Kaz Tiridi. Journal of Tourism and Gastronomy Studies, 5(4): 155-169.

[15] Güner, A., Doğruer, Y., Uçar, G., Yörük, H. D. (2002). Salam Üretiminde Kaz Etinin Kullanılabilme İmkanları. The Turkish Journal of Veterinary and Animal Sciences, 26: 1303-1308.

[16] Aşkın, Y. and İlaslan, M. (1976). Kars Bölgesi Kazlarında Ekonomik Önemi Olan Bazı Karakterler Üzerinde Araştırmalar. Ankara Üniversitesi Ziraat Fakültesi Yıllı̆̆ı, 26: 542-552.

[17] Dölekoğlu, C. Ö. (2002). Consumer Quality Preferences for Products, Attitude of Consumers on Health Risk and Nutritional Information (Adana Case). Unpublished Ph. D. Thesis, Çukurova University, Institute of Natural and Applied Sciences, Adana, 171 pp.

[18] Saraçlı, S. and Şıklar, E. (2005). Examining the Individual Retirement Account with Conjoint Analysis. Journal of Social Sciences, (2): 1-12.

[19] Erdoğan, C. (2006). Determining the Consumer Preference of Automobiles with Conjoint Analysis. Master Thesis, Gazi University, Institute of Natural and Applied Sciences, Ankara 75 pp.

[20] Álvarez-Farizo, B. and Hanley, N. (2002). Using Conjoint Analysis to Quantify Public Preferences over the Environmental Impacts of Wind Farms. An Example from Spain. Energy Policy, 30(2): 107-116.

[21] Poortinga W., Steg, L., Vlek, C., Wiersma, G. (2003). Household Preferences for Energy-Saving Measures: A Conjoint Analysis. Journal of Economic Psychology, 24(1): 49-64.

[22] Şen, H. and Çemrek, F. (2004). Konjoint Analizi ve Özel Dershane Tercihine Yönelik bir Uygulama. Eskişehir Osmangazi UniversityJournal of Social Sciences, 5(2): 105-120.

[23] Çamlıdere, Ö. (2005). Conjoint Analysis and an Application to Mobile Phones Preference. Master Thesis, Gazi University, Institute of Natural and Applied Sciences, Ankara, 64 pp.

[24] Tatlıdil, H. (2015). Siyasi Lider Profili-Konjoint Analizi Uygulaması. (Basılmamış Notlar).

[25] Çatpınar, H. (2005). Özel Sağlık Sigortalarında Konjoint Analizi ile Tüketici Tercihi. Sigorta Araştırmaları Dergisi, 1. 
[26] Dikici, T. (2006). Conjoint Analysis and an Application in Connection with Determination of Mobile Phone Preference of Consumers. Master Thesis, Uludag University, Institute of Social Sciences, Econometrics Department, Bursa, 113 pp.

[27] Sönmez, H. (2006). An Application of Consumer Preferences Via Conjoint Analysis: How to Choose a Home PC. Journal of Social Sciences, 6(2): 185-196.

[28] Soykan, Y. (2009). Conjoint Analysis in Industrial Purchasing Decisions and an Application. Akademik Bakış, 16: 1-18.

[29] Dinç, Y. (2010). Conjoint Analysis and an Application on the Selection Criteria of Automobile. Master Thesis, Marmara University, Institute of Social Sciences, Department of Statistics, Istanbul, 93 pp.

[30] Filiz, Z. and Şengöz, M. (2010). Kasko Sigortası Tercihinin Konjoint Analizi ile İncelenmesi. "İşGüç" Industrial Relations and Human Resources Journal, 12(1): 107-121.

[31] Turanlı, M., Bağdatlı Kalkan, S., and Yazılı, N. (2011). Customers’ Mobile Phone Package Choice and Price Flexibility Teste with Conjoint Analysis. Trakya University Journal of Social Science, 13 (2): 355-370.

[32] Çevik, O. and Yiğit, A. M. (2011). Determining Office Furniture Consumers' Preferences with Conjoint Analysis. Karamanoglu Mehmetbey University Journal of Social and Economic Research, 13 (20): 105-110.

[33] Bridges, J. F., Hauber, A. B., Marshall, D., Lloyd, A., Prosser, L. A., Regier, D. A., Johnson, F. R., and Mauskopf, J. (2011). Conjoint Analysis Applications in Health a Checklist: A Report of the ISPOR Good Research Practices for Conjoint Analysis Task Force. Value in Health, 14(4): 403-413.

[34] Aktaş, S., Akkuş, Ö. and Osmanoğlu, S. (2012). A Practical Study on the Performances of the Conditional Logit and Conjoint Analyses in the Modelling of the Polychotomous Dependent Variable. Istanbul Commerce University Journal of Science, 11(21): 25-40.

[35] Şahinkanat, E. (2013). Determination of Consumers' Purchasing Decisions with Conjoint Analysis. Master Thesis, Uludag University, Social Science Institution, Statistics Department, Bursa, 152 pp.

[36] Yavuz, S. and Çemrek, F. (2013). The Determination of Residental Preferences of Healthcare Workers Through Conjoint Analysis. Atatürk University Journal of Graduate School of Social Sciences, 17(2): 379-396.

[37] Ceylan, H. H. (2013). Market Segmentation Based on Benefit in Retail Sector by Using Conjoint and Cluster Analysis. CBU, Journal of Management and Economics, 20(1): 141-154.

[38] Baki, F., Saner, G., Adanacıoğlu, H., and Güler, D. (2017). A Conjoint Analysis of Consumer Preferences for Honeydew Honey in Turkey: A Case of İzmir Province. Balkan and Near Eastern Journal of Social Sciences, 3(2): 50-57.

[39] Yıldız, B. and Küçükkancabaş Esen, S. (2020). The Influence of Eco-Labelling on Consumer Behaviors: Examining Refrigerator Eco-Labels Using Conjoint Analysis. Productivity Journal (Verimlilik Dergisi), (1): 8398.

[40] Li, W., Long, R., Chen, H., Dou, B., Chen, F., Zheng, X., and He, Z. (2020). Public Preference for Electric Vehicle Incentive Policies in China: A Conjoint Analysis. International Journal of Environmental Research and Public Health, 17(1): 318.

[41] Hair, J. F., Anderson, R., Tatham, R., and Black, W.C. (1992). Multivariate Data Analysis, Third Edition, U.S.A.: Prentice Hall (Higher Education Division, Pearson Education), 480 pp.

[42] Kuhfeld, W.F. (2005). Marketing Research Methods in SAS. SAS 9.1 Edition.

[43] Çetinel, B. and Yeniay, O. (1997). Konjoint Analiz ve Cep Telefonu Pazarı Üzerine Bir Araştırma. 3. Ulusal Ekonometri ve İstatistik Sempozyumu Bildiri Kitabı, Bursa, 15-24. 
[44] Sönmez, H., (2001). The Usage of Conjoint Analysis in Marketing Research and an Application. Ph.D. Thesis, Anadolu University, Institute of Natural and Applied Sciences, Department of Statistics, Eskişehir, 183 pp.

[45] Orme, B. (2010). Getting Started with Conjoint Analysis: Strategies for Product Design and Pricing Research, 2nd Edition. Madison: Research Publishers LLC. 